\title{
From Covid-19 to a resilient metropolis: the example of the Great Nancy
}

Charlotte Copplet, Martine Batt, André Rossinot and Jane-Laure Danan

\section{(2) OpenEdition \\ Journals}

Electronic version

URL: http://journals.openedition.org/rfst/847

ISSN: 2492-3672

Publisher

Espaces et SOciétés (UMR 6590)

\section{Electronic reference}

Charlotte Copplet, Martine Batt, André Rossinot and Jane-Laure Danan, "From Covid-19 to a resilient metropolis: the example of the Great Nancy", Revue francophone sur la santé et les territoires [Online], Pandemic, crises and perspectives: territorial readings of Covid-19, Online since 18 February 2021, connection on 06 April 2021. URL: http://journals.openedition.org/rfst/847

This text was automatically generated on 6 April 2021.

\section{(c) (i) (9)}

La Revue francophone sur la santé et les territoires est mise à disposition selon les termes de la Licence Creative Commons Attribution - Pas d'Utilisation Commerciale - Partage dans les Mêmes Conditions 4.0 International. 


\title{
From Covid-19 to a resilient metropolis: the example of the Great Nancy
}

\author{
Charlotte Copplet, Martine Batt, André Rossinot and Jane-Laure Danan
}

1 Health promotion is a major focus of the metropolitan project of Grand Nancy. The city's second-generation local health contract has identified a network of local actors. This paper focuses on social and spatial issues of pandemic management and post containment. In response to the health risks associated with Covid-19, the metropolis has implemented measures to provide all its 20 communes with resources to prepare as best as possible for the ending stay-at-home restrictions in compliance with the health rules while seeking to promote and maintain the overall well-being of citizens.

2 This article aims to develop the strategies put in place to prepare social and societal recovery in the short and long term through a comprehensive approach to health in an inclusive and resilient territorial community. A multidisciplinary reflection cell has been installed before containment exit. This cell is composed of 32 experts including doctors, epidemiologists, hygienists, pharmacists, sociologists, elected officials... It met via video conference several times. This cell has been active since May 11 and has produced a list of 16 recommendations, formulated by experts. This material was the basis for reflection. At the same time, literature has been mobilized, in particular to confront this material with a theoretical framework in order to assess the psychosocial repercussions related to the containment situation and to determine the necessary actions to be put in place. Subsequently, a communication system between representatives of the communes and experts of the cell was established, allowing a reactivity and a response to the needs of the inhabitants as close as possible, at the initiative of the metropolis of Grand Nancy. To date, the cell has been requested 40 times for requests concerning the field of accompaniment and that of logistics. On the basis of these elements drawn from the literature and material collected through the expert unit (CRAC), the metropolis was able to prioritize the actions to be carried out. This work has given rise to a metropolitan resilience plan whose aim is to concretize 
the actions to be carried out. This action plan highlights 4 areas: support for the health crisis and cohesion of the metropolitan society, work and economic activities, mobility and public spaces, as well as education, culture, sport and hobbies. Thus, plans for the resumption of activity have been drawn up to reconcile the concern for efficient production to contribute to the revival of the territory with the health issues, as well as listening and support mechanisms for the agents. Have also been developed various actions to fight against school dropout, thanks to summer workshops as part of educational continuity or activities around digital inclusion. One of the largest project called "Prevention Consequences Containment" was developed in partnership with the Territorial Support Platform, who trained a hundred volunteer students, with the aim of preventing the risks of harmful psychological impacts caused by the containment situation, particularly post-traumatic type, and also to prevent hospitalizations of vulnerable confined persons. As part of the local health contract, the city is also given the mission to improve health information, communication and prevention, in particular by fighting against fake news. Finally, the bike plan is accelerated by experimenting with new bike paths, new pedestrian areas and redevelopment of urban infrastructure. Urban planning needs to be rethought to reflect the change in the way we share public space. Thus, the community has supported and put in place supports ranging from financial and logistical support, to the establishment of medicopsychological listening platforms. The local second-generation health contract has identified the metropolis as an essential lever in the field of health, especially in the context of crisis management. This study made it possible to highlight the indisputable lever that constitutes the Local Health Contract in terms of territorial organization of health. This contract has allowed the city, over the course of the health crisis, a certain agility alongside the field actors that are professionals of care, health, well-being.

Figure: Binding material between CRAC unit and the local representatives

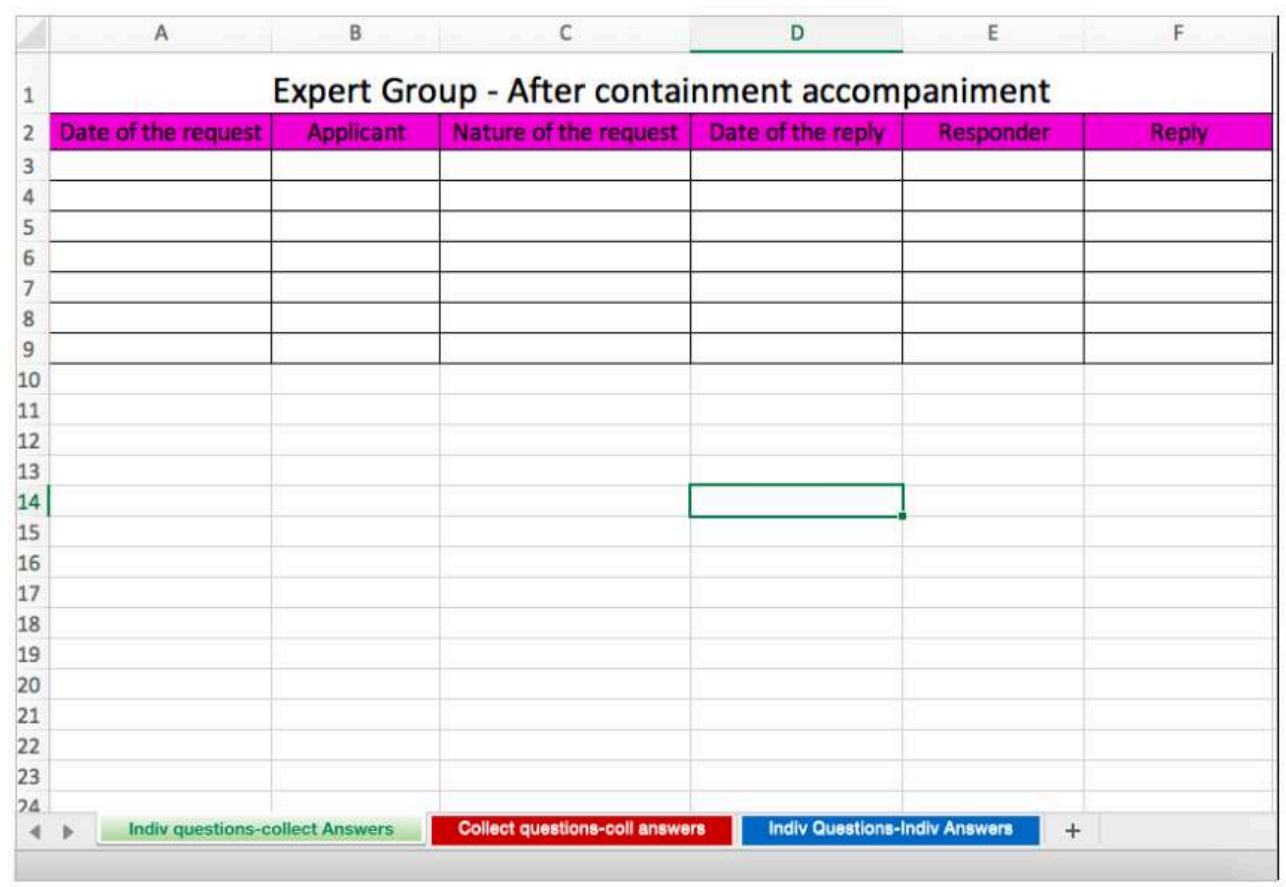

Source: internal document. 
Grand Nancy Metropolitan Area Health System Territorial Organization Proposal during COVID-19. Source: unpublished internal document. Reproduction authorized by the health mission of the metropolis.

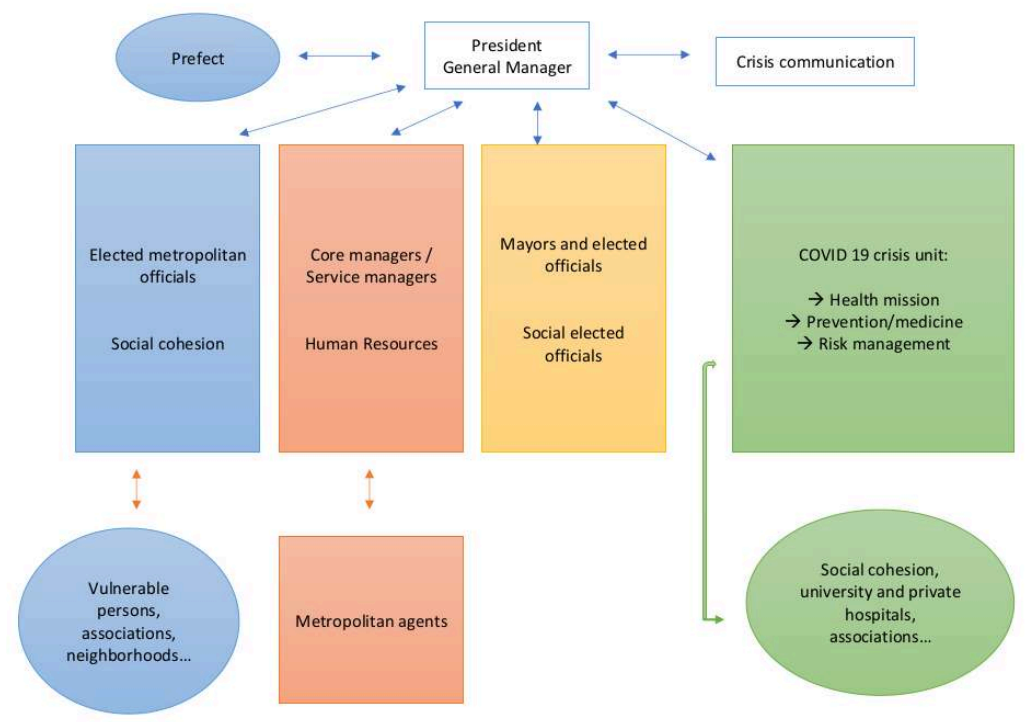

INDEX

Geographical index: Nancy

Keywords: management of the pandemic, containment outlet, individual resilience, urban resilience, social cohesion

\section{AUTHORS}

\section{CHARLOTTE COPPLET}

Étudiante en psychologie clinique et légale, France, Université de Lorraine

\section{MARTINE BATT}

Professeur de psychologie légale et psychopathologie, France, Université de Lorraine,

Responsable axe GRC, laboratoire INTERPSY 4432

\section{ANDRÉ ROSSINOT}

Docteur en médecine, ancien président de la Métropole du Grand Nancy, France.

\section{JANE-LAURE DANAN}

Docteur en sciences de la vie et de la santé, Responsable de la Mission Santé et Bien-Être. France, Métropole du Grand Nancy, Université de Lorraine, chercheur associé Axe PRISME, laboratoire INTERPSY 4432 